\title{
A Field Experiment on the Impact of Incentives on Milk Choice in the Lunchroom
}

\author{
John A. List ${ }^{\mathrm{a}}$ and Anya Samek ${ }^{\mathrm{b}}$ \\ ${ }^{a}$ University of Chicago and NBER \\ ${ }^{b}$ University of Wisconsin-Madison and the University of Chicago
}

December 31, 2014

\begin{abstract}
Almost a third of US children ages 2-19 are deemed overweight or obese, and part of the problem is the habitual decision to consume high calorie, low nutrient foods. We propose that the school lunchroom provides a 'teachable moment' to engage children in making healthful choices. We conduct a field experiment with over 1,500 participants in grades K-8 and evaluate the impact of small non-monetary incentives on the selection of milk in the school lunchroom. At baseline, only $16 \%$ of children select white milk relative to $84 \%$ choosing chocolate milk. We find a significant effect of incentives, which increase white milk selection by 2.5 times, to $40 \%$. One concern with incentives is that they may decrease intrinsic motivation to eat healthy, called 'crowd-out of intrinsic motivation.' However, we do not find evidence of 'crowd-out'; rather, we see some suggestive evidence of the positive habit forming effect of incentives.
\end{abstract}

JEL Classifications:

Keywords: field experiment, children, incentives, food choice

* Corresponding author: Anya Savikhin Samek - anyasamek@,gmail.com

We thank the Cornell Center for Behavioral Economics and Child Nutrition Programs for funding of this research. This experiment was implemented while Samek was at the University of Chicago and write-up was completed while Samek was at UW-Madison funded by the RIDGE Center for National Food and Nutrition Assistance Research. We thank Justin Holz, Tristin Ganter, Andrew Kramer, Christa Gibbs and Alannah Hoefler for excellent research assistance. 


\section{Introduction}

Obesity is a major public health concern, leading to many chronic conditions such as high blood pressure, diabetes, cardiovascular disease, and certain cancers (Pi-Sunyer, 1993). Obesity among children is of particular concern - $17 \%$ of youths in the United States have body mass indices (BMIs) at or above the recommended $95^{\text {th }}$ percentile (National Institutes of Health, 1998; Ogden et al., 2002, 2010). American children consume less than $20 \%$ of the recommended amount of whole grains and just $10 \%$ of the recommended amount of dark green and orange vegetables and legumes (Just et al., 2007). Lack of proper nourishment, such as not meeting the RDA requirements for fruits and vegetables, affects health and hampers growth among children and can also contribute to lack of concentration and energy, resulting in poor performance in school (Whitaker et al., 2006; Jyoti et al., 2005; Weinreb et al., 2002). Importantly, children from low-income families are at higher risk (Cole et al., 2008; Neumark-Sztainer et al., 1996). ${ }^{1}$

A major component of the obesity problem is the decision by individuals to habitually consume high quantities of low-nutrient, high-calorie foods and beverages. Poor eating habits are often learned in the home, which may create a cycle of unhealthy behaviors (De Bourdeaudhuij, 1997; Campbell et al., 2007; Dowda et al., 2001). We propose that the school lunchroom provides a 'teachable moment' for policymakers to reach children and improve food choice. The National School Lunch Program is an especially good place to reach low-income children, who are eligible for Free and Reduced Lunch and often eat the school-provided lunch. While one could simply dictate

\footnotetext{
${ }^{1}$ Lower-income students have less food security and are more likely to be overweight or obese, so targeting this socioeconomic group is of vital importance (Ogden et al., 2006).
} 
what foods go on a child's plate in this setting, research finds that children who choose foods on their own consume more than if they were required to take the foods (Hanks et al., 2013; Hakim and Messein, 2013). ${ }^{2}$

We designed a field experiment to investigate the impact of non-monetary incentives on children's milk choices - chocolate milk or white milk - in the school lunchroom. We decided to use milk choice as our outcome variable of interest not because it is the most nutritionally important decision that children make (we make no claim to be nutritionists), but because by virtue of sugar content, white milk is superior to chocolate milk ${ }^{3}$, and children have a clear preference for chocolate over white, so there is room to nudge behavior through our interventions.

In our experiment, we randomize children to either a baseline condition, or to an incentive condition where they can receive a glow-in-the-dark bracelet (valued at about $\$ 0.20)$ for selecting the healthier option. Incentives are a cornerstone of economics, and have been used successfully to encourage healthy food choice among children (e.g., List and Samek, 2014). We carried out the field experiment over a series of 9 days (2 weeks) with over 1,500 students in grades K-8 across 7 different elementary schools. We recorded the selection of milk as children went through the lunch-line.

We find that at baseline, only $16 \%$ of children select the healthier white milk relative to $84 \%$ choosing chocolate milk. We find a significant effect of incentives, which increase white milk selection to $40 \%$. After interventions are taken away, $25 \%$ of those previously treated continue to select white milk, providing suggestive evidence of the

\footnotetext{
${ }^{2}$ Conversely, Zeinstra et al. (2010) conducted a study on choice using a sample of Dutch children and did not find an overall effect, but did find an effect for children who are more sensitive to pressure.

${ }^{3}$ According to the National Dairy Council, chocolate milk has about 4 teaspoons of added sugar per $8 \mathrm{oz}$. serving, compared to 6 teaspoons in a $8 \mathrm{oz}$. serving of Coca-Cola.
} 
longer-term benefits of incentives, and no evidence of any negative effects.

The remainder of our paper proceeds as follows. In Section 2, we summarize the related literature on experiments in school lunchrooms, and provide an overview of possible impacts of incentives on school lunchroom choices. In Section 3, we present the design and procedures of our field experiment. Section 4 summarizes our results, and Section 5 concludes.

\section{Background}

\subsection{Related Literature}

The school cafeteria has been used in field experiments to investigate the effects of changing food presentation (Smith et al., 2013; Wansink and Just, 2013), taking advantage of marketing techniques by giving foods 'attractive names' (Wansink et al. 2012), point-of-purchase prompts (Schwartz, 2007; List and Samek, 2014b) and the effects of monetary incentives (Just and Price, 2013; Belot et al., 2013).

While many of these techniques have shown promise, incentives have been the most successful at improving food choice. For example, in a study with a group of 6-18 year-olds, List and Samek (2014) raised the proportion of children selecting and consuming fruit versus a cookie from $20 \%$ to $80 \%$ by offering a small non-monetary incentive linked to fruit consumption. Just and Price (2013) found similar effects on side dish consumption in the school cafeteria. In Cooke et al. (2011), incentivizing consumption of a disliked vegetable increased liking and consumption of the vegetable among K- $1^{\text {st }}$ graders 3 months later. Raju et al. (2010) investigated the impact of incentives, competition and pledges on fruit and vegetable consumption among $1^{\text {st }}-8^{\text {th }}$ 
graders, and found that incentives worked best. Incentives have also been effective in encouraging health behaviors among adults, such as weight loss (Cawley and Price, 2011, 2013; Volpp et al., 2008) smoking cessation (Volpp et al., 2009) and patient compliance with healthy behaviors (Giuffrida and Torgerson, 1997).

Finally, researchers have evaluated the 'Food Dude' program, which includes peermodeling videos combined with rewards, and found it to be effective for kids ages 4-11 both in Europe and in the U.S. (Lowe et al., 2004; Wengreen et al., 2013; Horne et al., 2008). However, while 'Food Dude' includes both social interaction and incentives, the effect of the two components has not been measured separately.

\subsection{Incentives}

The standard price effect in economics would predict that incentives work to modify behavior. In this case, introducing an incentive for choosing white milk would cause an increase in the selections of white milk relative to chocolate milk. However, as

pointed out by Gneezy et al. (2011), incentives may not always have the standard price effect. In the short run, incentives that are 'too small' may cause a crowd-out of intrinsic motivation, leading to a decrease in the incentivized behavior. For example, this result was shown in the study of Gneezy and Rustichini (2000), who found incentives to decrease performance. Incentives that are large enough will still lead to improvements.

After the intervention is removed, standard theory would suggest that milk choices would return to the pre-intervention levels. However, crowd-out theory has a different prediction: incentives could lead to decreases in white milk choice even relative to pre-intervention levels. Crowd-out could occur because students take the incentive as a 
signal that choosing white milk is too difficult, that it is not an attractive choice or if students believe that their choice of an incentivized white milk sends the wrong signal to others about their motivations (Gneezy et al., 2011; Deci, 1999). Extrinsic incentives may crowd out the intrinsic motivations resulting in a decrease in the desired behavior (Gneezy et al., 2011). Contrary to the prediction of crowd out, the theory of habit formation (Becker and Murphy, 1988), would instead have the long-run prediction that incentives will increase the levels of white milk choice post-intervention, above preintervention levels. Our experiment is designed to test both the impacts of incentives during and after the intervention. Because the intervention is short, we propose that we are unlikely to observe habit formation. However, we can at least explore whether the intervention introduced crowd-out.

\section{Experiment Design \& Procedures}

\subsection{The School Lunchroom}

The field experiments were conducted in the school lunch program in Chicago Heights School District 170 with 7 schools, grades K-8 and a total of 1,604 children participating. Chicago Heights has 31,000 residents with a mean household income of $\$ 14,963$. Over $90 \%$ of students in these districts qualify for the National Free or Reduced School Lunch. We find that in these schools, about $50 \%$ of students are overweight and $23 \%$ are obese by WHO standards. ${ }^{4}$ These districts have significant populations of minority students, including African-American (37.5\%) and Hispanic (23.8\%) students. ${ }^{5}$

During a typical lunch period, as children go through the cafeteria line, they receive

\footnotetext{
${ }^{4}$ These statistics were gathered in the Fall of 2009 at the beginning of a nutritional pilot study in which the height and weight of a representative sample of over 140 children were measured.

${ }^{5}$ Source: U.S. Census Bureau - State and County QuickFacts. Data derived from Population Estimates, 2000 Census of Population and Housing,
} 
the requisite main menu item, required side items, and then proceed to select milk, see Figure 1. According to guidelines set by the USDA, schools are required to provide students with two milk options - while options are left to the district, many districts choose to provide a white and a chocolate milk option. We learned from the lunchroom administrator in the district that chocolate milk is chosen as an option by administrators despite its greater sugar content, because most children prefer it. However, lunchroom administrators are eager to learn how to encourage students to take the white milk rather than the chocolate milk.

\section{Figure 1: The Lunchroom}

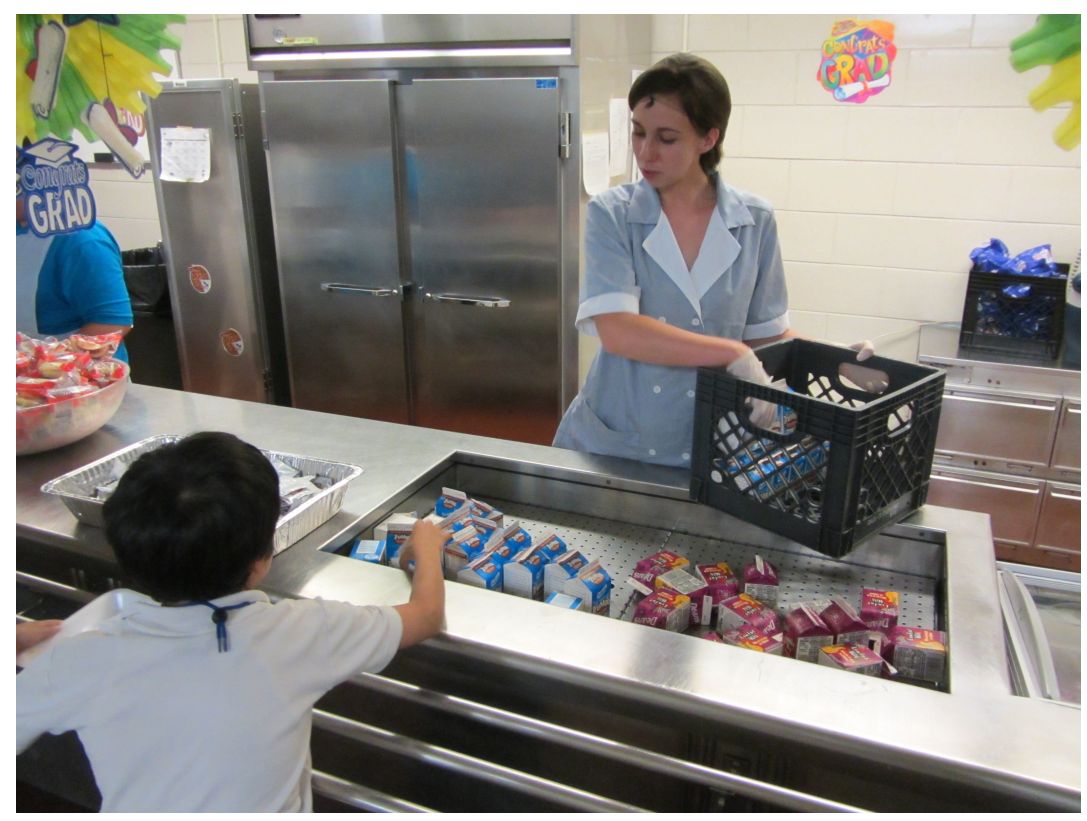

Students (and their parents) knew that they were in an experiment, but did not know what the experiment was about. Specifically, prior to the experiment we visited the lunchroom, explained to children that their choices would be recorded and that they may be eligible for prizes, but did not provide any additional information about the purpose of the experiment or the treatments. The children's parents also received 'reverse consent' forms by mail informing them that students' choices would be recorded and that they 
may receive prizes, and were able to opt their child out of the study if they wished by returning the form to their teacher. Only those students whose parents did not decline participation, and who assented, are in the dataset.

\subsection{Experimental Design}

We randomized students at the lunch period level to one of two different groups - a control group and a treatment group. The procedures for both groups were nearly identical. At the beginning of the lunch period, we put nametags on children to identify them. Then, children walked through the lunch-line to collect their meal (which did not involve a choice) and then made their choice of milk. In the control group, none of the choices were incentivized. In the treatment group, we stuck a glow-in-the-dark bracelet (valued at about $\$ 0.20$ ) onto all the white milk cartons, while the chocolate milk was not incentivized. After children left the lunch-line, and research assistants recorded the milk selected next to the child's name as they exited the lunch-line. After lunch was over, children left their trays on tables and research assistants weighed the milk remaining and visually recorded the amount of food remaining.

We are interested in evaluating milk choice after the intervention is removed. Therefore, we visited each lunchroom 9 times. The first time we visited the lunchrooms, we observed milk selection and consumption, without changing the environment. However, we noted that due to the students' preference for chocolate milk, cafeteria workers usually set out a greater amount of chocolate milk than white milk. Therefore, on Day 2 we changed the environment by providing an equal amount of chocolate and white milk at all times, and again observing selection and consumption. On Days 3-7, we maintained the environment created on Day 2 but for the treatment group, included the 
bracelets on all the white milks. Our incentives were glow-in-the dark bracelets that have a shelf life of 24 hours (the 'glow' fades), so we do not anticipate diminishing marginal utility for bracelets over treatment days.

Finally, to investigate the impact of our program after incentives are taken away, we ended with 2 observation days, during which the bracelets were again removed. Day 7 involved equal amounts of chocolate and white milk at all times, while Day 8 involved the original environment with more chocolate milk than white milk.

Table 1: Schedule

\begin{tabular}{ccll}
\hline & Days & \multicolumn{1}{c}{ Description } \\
\hline Pre-Treatment & $1-2$ & $\begin{array}{l}\text { Day 1 - "Regular" Lunch line } \\
\text { Day 2 - Display 1/2 white, 1/2 chocolate }\end{array}$ \\
\hline Treatment & $3-7$ & $\begin{array}{l}\text { Control } \\
\text { Days 3-7: No incentives. } \\
\text { Display 1/2 white, 1/2 } \\
\text { chocolate. }\end{array}$ & $\begin{array}{l}\text { Treatment } \\
\text { Days 3-7: Bracelets on white } \\
\text { but not chocolate. Display 1/2 } \\
\text { white, 1/2 chocolate. }\end{array}$ \\
\hline Post-Treatment & $8-9$ & $\begin{array}{l}\text { Day 8 - Display 1/2 white, 1/2 chocolate } \\
\text { Day 9- "Regular" Lunch line }\end{array}$ \\
\hline
\end{tabular}

\section{Results}

\subsection{Baseline Characteristics of Participants}

Table 2 provides a summary of the number of children who participated in each treatment, with additional descriptive statistics. We have data on 1,604 children, constituting 5,389 observed milk choices (not all children were present on all days). About half of children in the experiment were female, and children ranged in age from Kindergarten through $8^{\text {th }}$ grade. In the sample, about $59 \%$ of children are Hispanic, $37 \%$ 
are African-American, 3\% are white and the remainder is multiracial. ${ }^{6}$ Randomization was done at the school level with 3 schools in the control group and 4 schools in the treatment group ${ }^{7}$, so we are unbalanced on some demographic characteristics, which we thus control for in the analysis in sub-sections 4.2 and 4.3 .

Table 2: Number of Observations

\begin{tabular}{|c|c|c|c|c|c|c|}
\hline Treatment & $\begin{array}{c}\text { \# of } \\
\text { Students }\end{array}$ & $\begin{array}{c}\text { \# Milk } \\
\text { Observations }\end{array}$ & $\begin{array}{c}\text { Gender } \\
\text { (\% Fem.) }\end{array}$ & $\begin{array}{l}\text { Mean } \\
\text { Grade }\end{array}$ & $\begin{array}{l}\text { \% African } \\
\text { American }\end{array}$ & $\begin{array}{c}\% \\
\text { Hispanic }\end{array}$ \\
\hline Control & 907 & 2,567 & $52.9 \%$ & 3.09 & $29.9 \%$ & $68.6 \%$ \\
\hline Incentive & 697 & 1,524 & $55.7 \%$ & 3.41 & $44.9 \%$ & $46.9 \%$ \\
\hline
\end{tabular}

The pre-treatment Days 1-2 show that the proportion of children selecting white milk was comparable by treatment $-18.9 \%$ in Control, and $14.1 \%$ in Incentive. Chi^2 tests of proportions do not indicate any statistically significant differences between treatments on selection, either for the first pre-treatment day or the second ( $p$-values $=$ 0.32 and 0.14 , respectively).

\subsection{Effect of Incentives on Milk Choice}

We first investigate the impact of the incentives on white milk choice while they are in place. Figure 2 presents the proportion of children selecting white milk in each treatment, including all days over time. Averaging across all treatment days, we find strong and significant effects in the incentive treatment as compared to control: choice of

\footnotetext{
${ }^{6}$ Gender and race are obtained from school records. Grade is available, but not age.

${ }^{7}$ Only one school, which had in effect 2 lunch areas, was randomized with the right side of the lunchroom to the control group and the left side to the treatment group.
} 
white milk increases to $40 \%$ in the Incentive treatment, relative to $21 \%$ in the Control group (Wilcoxon Mann-Whitney non-parametric two-way comparison tests using white milk choice averaged by individual in Incentive versus Control yield $p$-value $<0.01)$. We also observe a significant difference when treating the lunch-period level (randomization level) as an independent observation ( $p$-value $=0.03$ ). This brings us to our first result:

Result 1: Non-monetary incentives significantly increase the likelihood of choosing white milk at the time of the intervention.

\section{Figure 2: White Milk Selection by Day and Treatment}

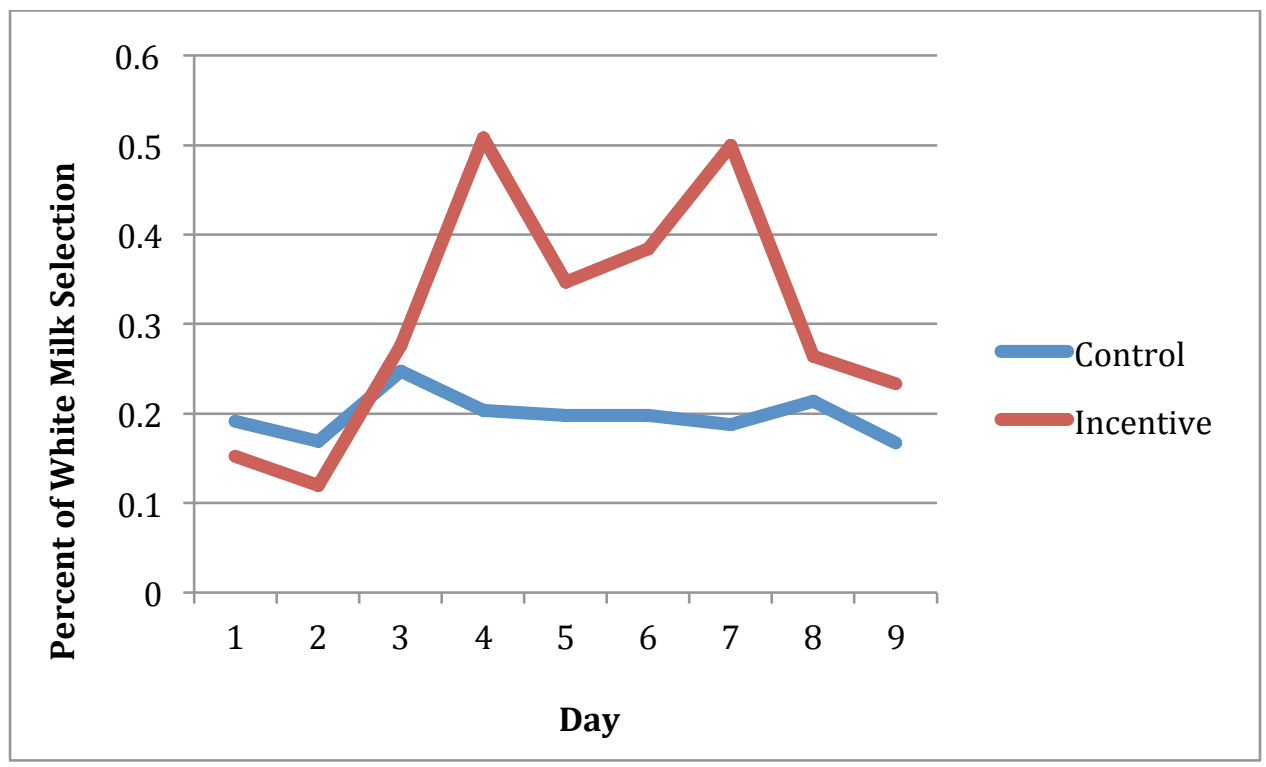

Table 3 presents statistical models that largely confirm Result 1 . We estimate a randomeffects logit model with dependent variable is white milk choice $(=1$ if white milk is chosen and $=0$ if chocolate is chosen). The variable Incentive Dummy represents the treatment effect. Only days 3-7 - the treatment days - are included in the regression, and we also include a period trend, Period. Specification (1) displays the overall result, Specification (2) introduces some demographic controls (Grade, Female, African- 
American, Hispanic) and Specification (3) includes demographic interaction terms

(Grade*Incentive, Female*Incentive, African-American*Incentive, Hispanic*Incentive).

Table 3: Logit Regressions on Selection of White Milk During Intervention

\begin{tabular}{|c|c|c|c|}
\hline & $\begin{array}{c}(1) \\
\text { Chose White } \\
\text { Days 3-7 }\end{array}$ & $\begin{array}{c}(2) \\
\text { Chose White } \\
\text { Days 3-7 }\end{array}$ & $\begin{array}{c}(3) \\
\text { Chose White } \\
\text { Days 3-7 }\end{array}$ \\
\hline $\begin{array}{l}\text { Incentive Dummy } \\
\text { (=1 for Incentive, } 0 \text { for control) }\end{array}$ & $\begin{array}{l}1.936^{* *} \\
(0.835)\end{array}$ & $\begin{array}{c}2.141 * * * \\
(0.578)\end{array}$ & $\begin{array}{l}1.458^{* *} \\
(0.708)\end{array}$ \\
\hline $\begin{array}{l}\text { Period } \\
\text { (Days 3-7) }\end{array}$ & $\begin{array}{c}0.0240 \\
(0.0658)\end{array}$ & $\begin{array}{c}0.0262 \\
(0.0576)\end{array}$ & $\begin{array}{c}0.0272 \\
(0.0605)\end{array}$ \\
\hline $\begin{array}{l}\text { Student's Grade } \\
\left(0=\text { Kindergarten, through } 8=8^{\text {th }}\right)\end{array}$ & & $\begin{array}{l}-0.0926 \\
(0.0912)\end{array}$ & $\begin{array}{l}-0.294^{*} \\
(0.162)\end{array}$ \\
\hline $\begin{array}{l}\text { Female Dummy } \\
(=1 \text { if Female, } 0 \text { if Male }\end{array}$ & & $\begin{array}{c}0.191 \\
(0.125)\end{array}$ & $\begin{array}{c}0.263 \\
(0.180)\end{array}$ \\
\hline $\begin{array}{l}\text { African-American Dummy } \\
(=1 \text { if African-American, } 0 \text { otherwise })\end{array}$ & & $\begin{array}{l}-0.785^{*} \\
(0.432)\end{array}$ & $\begin{array}{l}0.0201 \\
(0.329)\end{array}$ \\
\hline $\begin{array}{l}\text { Hispanic Dummy } \\
\text { (=1 if Hispanic, } 0 \text { otherwise })\end{array}$ & & $\begin{array}{l}-0.0857 \\
(0.244)\end{array}$ & $\begin{array}{l}-0.227 \\
(0.369)\end{array}$ \\
\hline $\begin{array}{l}\text { Grade*Incentive } \\
\text { (Incentive/Grade Interaction) }\end{array}$ & & & $\begin{array}{l}0.319^{*} \\
(0.187)\end{array}$ \\
\hline $\begin{array}{l}\text { Female*Incentive } \\
\text { (Incentive/Female Interaction) }\end{array}$ & & & $\begin{array}{l}-0.216 \\
(0.395)\end{array}$ \\
\hline $\begin{array}{l}\text { African-American*Incentive } \\
\text { (Incentive/African-Am. Interaction) }\end{array}$ & & & $\begin{array}{l}-1.133^{*} \\
(0.580)\end{array}$ \\
\hline $\begin{array}{l}\text { Hispanic*Incentive } \\
\text { (Incentive/Hispanic Interaction) }\end{array}$ & & & $\begin{array}{c}0.306 \\
(0.436)\end{array}$ \\
\hline Constant & $\begin{array}{l}-2.804 * * * \\
(0.869)\end{array}$ & $\begin{array}{l}-2.351 * * * \\
(0.698)\end{array}$ & $\begin{array}{c}-1.949 * * * \\
(0.576)\end{array}$ \\
\hline Observations & 2,834 & 2,794 & 2,794 \\
\hline Number of Student IDs & 845 & 830 & 830 \\
\hline
\end{tabular}

Note: Robust standard errors in parentheses. Standard errors clustered at the school level. Includes individual student fixed effects. A series of regressions that include the choice of white milk on the first baseline day as an additional control arrive at qualitatively similar results.

$* * * \mathrm{p}<0.01, * * \mathrm{p}<0.05, * \mathrm{p}<0.1$

A positive and significant coefficient on Incentive in all specifications confirms

Result 1, that incentives significantly increase the choice of white milk. In Specification (2), we see that for the most part, different demographic characteristics do not predict greater or less likelihood of selecting white milk. The only exception is the negative and marginally significant coefficient on African-American Dummy, suggesting that African- 
American children in our sample are somewhat less likely to select white milk. We also observe interesting results with regards to the interaction between demographics and treatment. Older children are more affected by the incentive, as evidenced by the positive and marginally significant coefficient on Grade*Incentive. African-American children are not as affected by the incentive as Caucasian or Hispanic children, since the interaction term African-American*Incentive is negative and significant at the $10 \%$ level.

\subsection{Results Following the Intervention}

Next, we investigate the effect of incentives once the intervention is taken away. Unlike in List and Samek (2014), who investigated the use of non-monetary incentives in after-school programs, our school lunchroom setting allows us to observe the same children on a regular basis, which increases the inference we can draw from the postintervention results. As displayed in Figure 2, we see that white milk choice declines after the incentive is taken away, but we still observe a higher white milk choice in the PostTreatment days for Incentive as compared to for the Control group. In particular, while treatment group children are selecting white milk about $25 \%$ of the time, control group children are selecting white milk only $18 \%$ of the time. A 1-sided t-test rejects any evidence of crowd-out, that is, the white milk selection in the treatment group is not lower than the control group ( $p$-value $=0.05$ for the $t$-test and the non-parametric Wilcoxon-Mann-Whitney test). However, we cannot reject that the treatment group is

different from the control group at conventional levels (the 2 -sided $p$-value $=0.11$ ), so it is hard to say whether we have observed any habit-formation either. 
We turn to a regression to extend our results, reported in Table 4. We again use a logit random effects regression, this time focusing on just the two days after the intervention is removed (days 8-9). The regression tells a similar story as the 2-sided tests. The coefficient on Incentive is positive and insignificant in Specifications (1) and (2), and negative and insignificant in Specification (3). No interesting interaction effects are observed.

Table 4: Logit Regressions on Selection of White Milk After Intervention

\begin{tabular}{|c|c|c|c|}
\hline & $\begin{array}{c}(1) \\
\text { Chose White } \\
\text { Days 8-9 }\end{array}$ & $\begin{array}{c}(2) \\
\text { Chose White } \\
\text { Days 8-9 } \\
\end{array}$ & $\begin{array}{c}(3) \\
\text { Chose White } \\
\text { Days 8-9 }\end{array}$ \\
\hline $\begin{array}{l}\text { Incentive Dummy } \\
(=1 \text { for Incentive, } 0 \text { for control) }\end{array}$ & $\begin{array}{c}0.906 \\
(5.594)\end{array}$ & $\begin{array}{c}1.206 \\
(5.197)\end{array}$ & $\begin{array}{l}-2.726 \\
(10.07)\end{array}$ \\
\hline $\begin{array}{l}\text { Period } \\
\quad \text { (Days 3-7) }\end{array}$ & $\begin{array}{c}-1.016^{* *} \\
(0.508)\end{array}$ & $\begin{array}{l}-1.100 \\
(0.680)\end{array}$ & $\begin{array}{l}-1.027^{*} \\
(0.617)\end{array}$ \\
\hline $\begin{array}{l}\text { Student's Grade } \\
\left(0=\text { Kindergarten, through } 8=8^{\text {th }}\right)\end{array}$ & & $\begin{array}{l}0.235 \\
(0.288)\end{array}$ & $\begin{array}{l}-0.0522 \\
(0.0566)\end{array}$ \\
\hline $\begin{array}{l}\text { Female Dummy } \\
(=1 \text { if Female, } 0 \text { if Male }\end{array}$ & & $\begin{array}{l}1.505 \\
(1.042)\end{array}$ & $\begin{array}{c}0.912 \\
(0.693)\end{array}$ \\
\hline $\begin{array}{l}\text { African-American Dummy } \\
(=1 \text { if African-American, } 0 \text { otherwise })\end{array}$ & & $\begin{array}{l}0.665 \\
(0.721)\end{array}$ & $\begin{array}{c}0.923 \\
(1.128)\end{array}$ \\
\hline $\begin{array}{l}\text { Hispanic Dummy } \\
(=1 \text { if Hispanic, } 0 \text { otherwise })\end{array}$ & & $\begin{array}{c}1.549 \\
(1.210)\end{array}$ & $\begin{array}{c}0.823 \\
(1.163)\end{array}$ \\
\hline $\begin{array}{l}\text { Grade*Incentive } \\
\text { (Incentive/Grade Interaction) }\end{array}$ & & & $\begin{array}{c}0.812 \\
(0.851)\end{array}$ \\
\hline $\begin{array}{l}\text { Female*Incentive } \\
\text { (Incentive/Female Interaction) }\end{array}$ & & & $\begin{array}{l}1.619 \\
(2.237)\end{array}$ \\
\hline $\begin{array}{l}\text { African-American*Incentive } \\
\text { (Incentive/African-Am. Interaction) }\end{array}$ & & & $\begin{array}{l}-0.383 \\
(1.425)\end{array}$ \\
\hline $\begin{array}{l}\text { Hispanic*Incentive } \\
\text { (Incentive/Hispanic Interaction) }\end{array}$ & & & $\begin{array}{l}1.403 \\
(2.527)\end{array}$ \\
\hline Constant & $\begin{array}{l}0.367 \\
(2.495)\end{array}$ & $\begin{array}{l}-1.572 \\
(2.444)\end{array}$ & $\begin{array}{l}-0.372 \\
(2.843)\end{array}$ \\
\hline Observations & 992 & 977 & 977 \\
\hline Number of Student IDs & 637 & 625 & 625 \\
\hline
\end{tabular}

Note: Robust standard errors in parentheses. Standard errors clustered at the school level. Includes individual student fixed effects. A series of regressions that include the choice of white milk on the first baseline day as an additional control arrive at qualitatively similar results.

$* * * \mathrm{p}<0.01, * * \mathrm{p}<0.05, * \mathrm{p}<0.1$ 
We thus conclude that there is no evidence for crowd-out of intrinsic motivation in our data, rather the standard price effect is more likely as coefficients on Incentive Dummy are insignificant. In addition, we see some suggestive evidence in favor of habitformation, though more work is needed with longer-term interventions to know for sure whether incentives can lead to healthy habits. This brings us to the second, and final result:

Result 2: Incentives do not result in crowd-out of intrinsic motivation, as measured by the likelihood of choosing white milk after the incentives are taken away.

\section{Discussion \& Conclusion}

We set out to discover low-cost, scalable nudges to improve child food choice and consumption during a teachable moment: the school lunch line. Our sample consisted of over 1,500 children from low-income households in the Chicago Heights, Illinois school district, who may be at highest risk for poor nutrition. We were motivated to investigate the impact of incentives valued at about 15 cents each. Moreover, we were interested in learning whether and how incentive programs affect children after the incentive is removed.

We found a large and significant positive impact of incentives: the introduction of a small non-monetary incentive for choosing white milk in the school lunch-line increased the likelihood of selecting white milk by 2.5 times. This result is in line with recent work on the power of incentives, including List and Samek (2014), Just and Price (2013) and Belot et al. (2013). The related studies provided incentives following the decision to choose healthy; on the other hand, our study is the first to incorporate incentives directly into the decision by affixing the incentive directly onto the milk 
carton. Providing the incentive in this way could be more cost effective, since affixing a bracelet to a milk carton is relatively less time intensive than tracking decisions made by children and providing rewards later.

Importantly, we investigated the impact of incentives longer-term, after the incentive was taken away. While List and Samek (2014) consider long-term impacts, finding some evidence for the positive impact of incentives in inducing the formation of healthy habits, their estimates can be considered a lower bound since many children in their after-school program are not present each day. On the other hand, our school lunchroom setting, with more regular attendance, is a great environment to study longterm effects.

We found no evidence that incentives crowd-out intrinsic motivation to choose the healthier white milk, as may be predicted by some theories (e.g., Deci, 1999). On the other hand, we found some suggestive evidence for habit formation, as children continued to choose the healthier white milk after the incentive was taken away. These results speak to the possibility of using a short-term intervention that includes incentives, without necessarily hurting long-term outcomes.

While a series of papers have now documented the powerful effect of incentives on child food choice in the school lunch-line, several questions remain un-answered and are left to future work. For purposes of calculating the costs and benefits of incentive programs for policy applications, it will be useful to know whether higher valued incentives increase the likelihood of choosing healthy, and whether lower valued incentives do worse. To further our understanding of the possible habit-forming ability of 
incentives, future work should also investigate how the length of intervention affects habit-formation, and whether and how quickly habits regress over time.

\section{References}

Becker, G. \& Murphy, K. (1988). A Theory of Rational Addiction. The Journal of Political Economy, Vol. 96, No. 4. 675-700

Belot, Michele; James, Jonathan and Nolen, Patrick. Changing Eating Habits - a Field Experiment in Primary Schools, SIRE Discussion Paper SIRE-DP-2013-44.

Campbell, K. J., Crawford, D. A., Salmon, J., Carver, A., Garnett, S. P., \& Baur, L. A. (2007). Associations between the home food environment and obesity-promoting Eating Behaviors in Adolescence. Obesity, 15(3), 719-730.

Cawley, J., \& Price, J. A. (2011). Outcomes in a Program that Offers Financial Rewards for Weight Loss. In Economic Aspects of Obesity (pp. 91-126). University of Chicago Press.

Cawley, J., \& Price, J. A. (2013). A case study of a workplace wellness program that offers financial incentives for weight loss. Journal of health economics, 32(5), 794-803.

Cole, N. \& Fox, M. K. (2008). Diet quality of American young children by WIC participation status: data from the National Health and Nutrition Examination Survey, 1999-2004. Report No. WIC-08-NH. Alexandria, VA: U.S. Department of Agriculture, Food and Nutrition Service, Office of Analysis, Nutrition, and Evaluation.

Cooke, L. J., Chambers, L. C., Añez, E. V., Croker, H. A., Boniface, D., Yeomans, M. R., \& Wardle, J. (2011). Eating for Pleasure or Profit The Effect of Incentives on Children's Enjoyment of Vegetables. Psychological science, 22(2), 190-196.

De Bourdeaudhuij, I. (1997). Family food rules and healthy eating in adolescents. Journal of Health Psychology, 2(1), 45-56.

Deci, E., Koestner, R., \& Ryan, R. (1999). A Meta-analytic Review of Experiments Examining the Effects of Extrinsic Rewards on Intrinsic Motivation. Psychological Bulletin, 125(6): 627-68.

Dowda, M., Ainsworth, B. E., Addy, C. L., Saunders, R., \& Riner, W. (2001). 
Environmental influences, physical activity, and weight status in 8-to 16-year-olds. Archives of Pediatrics and Adolescent Medicine, 155(6), 711-717.

Giuffrida, A., \& Torgerson, D. J. (1997). Should we pay the patient? Review of financial incentives to enhance patient compliance. BMJ: British Medical Journal, 703-707.

Gneezy, U. \& Rustichini, A. (2000). Pay Enough or Don't Pay At All. Quarterly Journal of Economics, 115(3): 791-810.

Gneezy, U., Meier, S., \& Rey-Biel, P. (2011). When and Why Incentives (Don't) Work to Modify Behavior. The Journal of Economic Perspectives, Vol. 25, No. 4, 191-209.

Hakim, S. M., \& Meissen, G. (2013). Increasing consumption of fruits and vegetables in the school cafeteria: the influence of active choice. Journal of health care for the poor and underserved, 24(2), 145-157.

Hanks, A., Just, D., \& Wansink, B. (2012). Trigger Foods: The Influence of'Irrelevant'Alternatives in School Lunchrooms. Agricultural and Resource Economics Review.

Hanks, A. S., Just, D. R., \& Wansink, B. (2013). Preordering School Lunch Encourages Better Food Choices by Children. JAMA pediatrics, 167(7), 673-674.

Horne, P. J., Hardman, C. A., Lowe, C. F., Tapper, K., Le Noury, J., Madden, P., \& Doody, M. (2009). Increasing parental provision and children's consumption of lunchbox fruit and vegetables in Ireland: the Food Dudes intervention. European Journal of Clinical Nutrition, 63(5), 613-618.

Just, D., Lisa, M., \& Brian, W. (2007). Could behavioral economics help improve diet quality for nutrition assistance program participants? Economic Research Report No. 43, U.S. Department of Agriculture, Economic Research Service.

Just, D. R., \& Price, J. (2013). Using incentives to encourage healthy eating in children. Journal of Human Resources, 48(4), 855-872.

Just, D., \& Price, J. (2013). Default options, incentives and food choices: evidence from elementary-school children. Public health nutrition, 16(12), 2281-2288.

Jyoti, D., Frongillo, E., \& Jones, S. (2005). Food insecurity affects school children's academic performance, weight gain, and social skills. Journal of Nutrition. 135, 28312839. 
List, John A., and Anya Savikhin Samek. (2014) The Behavioralist as Nutritionist: Leveraging Behavioral Economics To Improve Child Food Choice and Consumption. Journal of Health Economics, forthcoming.

Lowe, C. F., Horne, P. J., Tapper, K., Bowdery, M., \& Egerton, C. (2004). Effects of a peer modelling and rewards-based intervention to increase fruit and vegetable consumption in children. European journal of clinical nutrition, 58(3), 510-522.

National Institutes of Health. (1998). Clinical guidelines on the identification, evaluation, and treatment of overweight and obesity in adults: The evidence report. Bethesda, MD: National Heart, Lung and Blood Institute.

Neumark-Sztainer, D., Story, M., Resnick, M. D., \& Blum, R. W. (1996). Correlates of inadequate fruit and vegetable consumption among adolescents. Preventive Medicine 25(5):497-505.

Ogden, C. L., Carroll, M. D., Curtin, L. R., Lamb, M. M., \& Flegal, K. M. (2010). Prevalence of high body mass index in US children and adolescents, 2007-2008. Journal of the American Medical Association, 303(3), 242-249.

Ogden, C. L., Flegal, K. M., Carroll, M. D., \& Johnson, C. L. (2002) Prevalence and trends in overweight among US children and adolescents, 1999-2000. The Journal of the American Medical Association, 288(14),1728-1732.

Pi-Sunyer FX. (1993). Short-term medical benefits and adverse effect of weight loss. Annals of Internal Medicine, 199 (7 Pt 2), 722-6.

Raju, S., Rajagopal, P., \& Gilbride, T. J. (2010). Marketing healthful eating to children: the effectiveness of incentives, pledges, and competitions. Journal of Marketing, 74(3), 93-106.

Smith, L., Conroy, K., Wen, H., Rui, L., \& Humphries, D. (2013). Portion size variably affects food intake of 6-year-old and 4-year-old children in Kunming, China. Appetite, 69, 31-38.

Schwartz, M. B. (2007). The influence of a verbal prompt on school lunch fruit consumption: a pilot study. International Journal of Behavioral Nutrition and Physical Activity, 4(6).

Volpp, K. G., John, L., K., Troxel, A. B., Norton, L., Fassbender, J., Loewenstein, G.(2008). Financial incentive-based approaches for weight loss: A randomized trial. Journal of the American Medical Association, 300(22), 2631-2637.

Volpp, K. G., Troxel, A. B., Pauly, M. V., Glick, H. A., Puig, A., Asch, D. A., ...Audrain- 
McGovern, J. (2009). A randomized, controlled trial of financial incentives for smoking cessation. New England Journal of Medicine, 360(7), 699-709.

Wansink, B., \& Just, D. (2011). Healthy foods first: students take the first lunchroom food $11 \%$ more often than the third. Journal of nutrition education and behavior, 43(4), S8.

Wansink, B., Just, D. R., Payne, C. R., \& Klinger, M. Z. (2012). Attractive names sustain increased vegetable intake in schools. Preventive medicine, 55(4), 330-332.

Weinreb, L., Wehler, C., Perloff, J., Scott, R., Hosmer, D., Sagor, L., \& Gundersen, C. (2002). Hunger: Its impact on children's health and mental health. Pediatrics 110, e41.

Wengreen, H. J., Madden, G. J., Aguilar, S. S., Smits, R. R., \& Jones, B. A. (2013). Incentivizing Children's Fruit and Vegetable Consumption: Results of a United States Pilot Study of the 'Food Dudes' Program. Journal of nutrition education and behavior, 45(1), 54-59.

Whitaker, R., Phillips, S., \& Orzol, S. (2006). Food insecurity and the risks of depression and anxiety in mothers and behavior problems in their preschool-aged children.

Pediatrics, 118 (3), e859-e868.

Zeinstra, Gertrude G., et al. "Offering choice and its effect on Dutch children's liking and consumption of vegetables: a randomized controlled trial." The American journal of clinical nutrition 91.2 (2010): 349-356. 


\section{Appendix - Experiment Procedure and Survey Script \\ 1. Experiment protocol (in addition to what children normally do)}

In order to conduct a study of milk choice and how short and long term prompts and incentives affect choice, the following additions will be implemented.

- While children stand in line before going to the lunch counter, an RA will put a sticker on each child with their first name, classroom number, and date/time (Kindergarteners will be asked to line up in alphabetical order to make the process easier)

- When walking through the lunchroom, as children pick up their milk (chocolate or regular) they will put their ID sticker on the milk

- Children will also receive a prompt or incentive during the "Treatment" days depending on which treatment they are randomized into

- Children will sit down and eat lunch as normal

- Data will be entered into the computer and we will match each child's name with a random unique ID, and the original will be destroyed at the end of the study

\section{Control \& Incentive}

In the control, children will only be observed, but an RA will help put the milk out to assure conformity with the other sites. In incentive, the only difference is that a bracelet is attached to each white milk carton. 